Meta

Journal des traducteurs

Translators' Journal

\title{
When the Focus of the Text is Blurred: A Textlinguistic Approach for Analyzing Student Interpreters' Errors
}

\section{Abdullah Shakir et Mohammed Farghal}

Volume 42, numéro 4, décembre 1997

URI : https://id.erudit.org/iderudit/004121ar

DOI : https://doi.org/10.7202/004121ar

Aller au sommaire du numéro

\section{Éditeur(s)}

Les Presses de l'Université de Montréal

ISSN

0026-0452 (imprimé)

1492-1421 (numérique)

Découvrir la revue

Citer cet article

Shakir, A. \& Farghal, M. (1997). When the Focus of the Text is Blurred: A

Textlinguistic Approach for Analyzing Student Interpreters' Errors. Meta, 42(4), 629-640. https://doi.org/10.7202/004121ar

\section{Résumé de l'article}

Cette étude vise à identifier l'effet produit, sur l'interprétation simultanée arabe-anglais, lorsque le traducteur sous-estime la valeur de deux types de composantes textuelles : les conjonctions et les items lexicaux clés. Le texte source est d'un type qui vise à convaincre, ce qui demande de la part du récepteur de la traduction la même base socio-historique que le récepteur du texte original. La recherche est basée sur l'hypothèse que, dans ce type de texte, les conjonctions et les éléments lexicaux jouent un rôle important pour faire ressortir la pragmatique de la communication. La recherche étudie comment cinq conjonctions arabes et quatre éléments lexicaux émotivement chargés ont été traduits en anglais par dix étudiants de maîtrise en traduction. Les résultats montrent que la majorité des étudiants ont mal traduit les conjonctions et que leur travail a un effet négatif sur la finalité du texte. De même, les éléments lexicaux émotivement chargés ont été neutralisés par les étudiants. L'auteur termine avec des suggestions sur les méthodes d'enseignement et le contenu des cours en interprétation à l' Université Yarmouk.
Tous droits réservés @ Les Presses de l'Université de Montréal, 1997
Ce document est protégé par la loi sur le droit d'auteur. L’utilisation des services d’Érudit (y compris la reproduction) est assujettie à sa politique d'utilisation que vous pouvez consulter en ligne.

https://apropos.erudit.org/fr/usagers/politique-dutilisation/ 


\title{
WHEN THE FOCUS OF THE TEXT IS BLURRED: A TEXTLINGUISTIC APPROACH FOR ANALYZING STUDENT INTERPRETERS' ERRORS
}

\author{
ABDULLAH SHAKIR AND MOHAMMED FARGHAL \\ Yarmouk University, Irbid, Jordan
}

\begin{abstract}
Résumé
Cette étude vise à identifier l'effet produit, sur l'interprétation simultanée arabe-anglais, lorsque le traducteur sous-estime la valeur de deux types de composantes textuelles: les conjonctions et les items lexicaux clés. Le texte source est d' un type qui vise à convaincre, ce qui demande de la part du récepteur de la traduction la même base socio-historique que le récepteur du texte original. La recherche est basée sur l'hypothèse que, dans ce type de texte, les conjonctions et les éléments lexicaux jouent un rôle important pour faire ressortir la pragmatique de la communication.

La recherche étudie comment cinq conjonctions arabes et quatre éléments lexicaux émotivement chargés ont été traduits en anglais par dix étudiants de maîtrise en traduction. Les résultats montrent que la majorité des étudiants ont mal traduit les conjonctions et que leur travail a un effet négatif sur la finalité du texte. De même, les éléments lexicaux émotivement chargés ont été neutralisés par les étudiants. L'auteur termine avec des suggestions sur les méthodes d'enseignement et le contenu des cours d' interprétation à l'Université Yarmouk.

Abstract

This study aims to investigate the effect of missing the pragmatic impact of two textual components, viz., conjunctives and key lexical items, on the typological focus of the source text in the process of simultaneous interpreting from Arabic into English. The source text assumes a hortative function which calls into the recipient's active socio-historical memory, events and experiences comparable to those addressed in the text. The investigation is based on the assumption that in a hortative text conjunctives and lexical items play a significant role in displaying the pragmatics of the communicative event.

The study investigates how five Arabic conjunctives and four emotively-loaded lexical items in the text were rendered in English by ten M.A. (Translation) students. This research has shown that the conjunctives were inappropriately rendered by most of the student interpreters, and that such renderings distorted the intended argument of the text. Results also reveals that the interpretations provided of the four key lexical items stripped them of their emotive charge, thus neutralizing the argument of the text. The study concludes with suggestions concerning the methods of teaching interpreting and the content of the interpreting course at Yarmouk University. The suggestions are based on the implications derived from the analysis of both the source text and the students' renderings of the conjunctives and the lexical items.
\end{abstract}

\section{INTRODUCTION}

Bowen and Bowen (1984) speak of interpretation as the process which retains "the same thing as the original. [...] It may not omit any facts [...] It may not slant the message." One of the key points stressed in the above definition is the notion of sameness of message to be retained in the target language $(T L)$ version. The notion echoes a more technical term which has provoked a plethora of research in the field of translation, viz., the notion of translation equivalence (TE). 
Researchers have approached TE from different perspectives; yet all seem to have been addressing the same broad question: maximizing the degree of sameness that should be established in the TL text as a second version of the source language (SL) text. To some translation theorists, e.g. Catford (1965), a translated version should maintain formal/ grammatical equivalence of the source text. Thus, he views equivalence within the framework of replacing textual material in the source text by equivalent textual material in the target text. In such a view, providing formal correspondence at both micro- and macrolevels (i.e. at the grammatical and organizational levels) constitutes a major requirement for establishing translation equivalence. This view, however, has been called into question by other translation theorists, e.g. Nida (1990; 1977), de Waard and Nida (1986), Jakobson (1959), who viewed translation as a process initiated by factors from within and from without the text. To them, the end product of a translated version is a message in the TL equivalent to that of the SL in its rhetorical orientation and, consequently, its intended influence on the SL audience. Such a view brings to the fore the communicative event together with the contextual elements encompassed by the discursvie situation which includes the what, the who, the where, and the why aspects of the communicative interaction.

Few researchers, however, have explored the ways in which a translated version manages or fails to render the message as intended by the speaker/writer. It was only recently that researchers, e.g. Hatim and Mason (1990), Lotfipour-Saedi (1990), Farghal (1990), Shakir (1992), looked into discursive problems which can impede rendering communicatively acceptable translations / interpretations. The scope of investigation has, thus, expanded to accommodate the interlock between textual features and contextual elements on the one hand, and the way they interact to shape both the message and form of the text, on the other.

\section{THE PRESENT STUDY}

The central purpose of this study is to investigate the effect of missing the pragmatic impact of two textual components, viz. conjunctives and lexical items, on the typological focus of the source text in the process of simultaneous interpreting. The research is based on the assumption that in expressive discourse, such as the one we are dealing with, conjunctives and key lexical items play a significant role in indexing the pragmatics of the verbal communicative event. Such pragmatics-indexing items are marks of the surface structure of the text whose content and implications derive from "social memory" (Shi-xu 1992) which forms a frame of reference to both the text producer and text recipient.

Conjunctives represent sign-posts deployed at the boundaries of discoursal units/ planes to enable the text recipient to follow the thread of the discourse and, consequently, to decipher the progression of the argument. Key lexical items, on the other hand, are content-loaded discoursal cells knitted into the web of the discourse and charged with meanings deriveable from the social cognitive memory. The amalgamation of conjunctives and key lexical items yields a constellation of features which characterize the abstract notion of text typological focus.

The text we are dealing with lends itself to hortatory discourse (a sub-type of argumentative and persuasive text: Longacre and Levinsohn 1978) which typically aims at advising, warning, and/or reminding of unwanted consequences. Such texts tend to be prototypical in content, function, and structure. Virtanen (1992) speaks of prototoypes as consisting of core and periphery. Core refers to the abstract - to the notion of type, whereas periphery refers to the surface realization of the text.

The notion of prototype fits very well into our analysis of the students' interpretations, as we assume that the above textual elements are displays of textual characteristics familiar to both the text producer and the audience, of whom the student interpreters are 
members. Being a hortative text (prototypically textured), it expresses attitudes, ideologies, beliefs and other emotive elements. This being so, the speaker/writer mobilizes text strategic key elements in an attempt to maximize the audience's orientation and responsive attitude. This target reciprocity of response is achievable only if the addresser can make salient an aggregate of features whose signification is retrievable from shared frames of reference, that is, when the text recipient is able to reconstruct ideologies, beliefs, and attitudes from the discourse.

The subjects of the study were ten M.A. translation students who sat for the comprehensive exam held at the Language Centre at Yarmouk University in 1992. Simultaneous interpretation constituted one of the components of the test, and the material for this component was recorded by one of the present researches.

\section{ANALYSIS AND DISCUSSION}

As was previously mentioned, the text the student interpreters dealt with is hortative in its function, argumentative in its structure. It sets forth a thesis specifying what should be done by the Arab states to provide support of the peoples of Bosnia and Herzegovina. The argument throughout calls for support; and such a call drives deep into religious beliefs and political ideologies which seem to have motivated the argument. The text maintains a hortative tone, warning against and reminding of potential consequences of the passive stance the Arabs have taken with regard to the massacre of the Moslems in Bosnia and Herzegovina. This hortative tone is made explicit through textual organization, with conjunctives either initiating the argument in each discoursal unit/plane, or performing a retrospective role, thus interlocking discoursal units. The role conjunctives play in establishing typological focus in the text in question will be discussed below.

\subsection{The Role of Conjunctives}

In order to bring out the pragmatic role played by target conjunctives, we will provide a semantic display of the text's macro-structural components. Our concern with conjunctives stems from a discoursal phenomenon in Arabic (and perhaps in other languages) where we find that hortatory discourse leans heavily on conjunctives to make explicit the function of the units that make up the discourse. In this view, conjunctives are used to key stance, attitudes and feelings. They operate on sequences of predications (Ochs and Schieffelin 1989) to indicate the upcoming argument, or to terminate one. Thus, the communicative power of a conjunctive is not inherent in it; rather, it derives from the nature of the discoursal slot it occupies. It takes on, in this sense, a social or expressive role (Schiffrin 1987). The selection of a conjunctive in hortative texts (and, of course, in other text types) is usually constrained by their discoursal environment.

Our text can be divided into the following discoursal units, as displayed in Figure 1.

Unit 1: Thesis calling for a course of action to be taken by Arab states (sentence 1).

Unit 2: Substantiation: justifying the call raised in Unit 1 (sentence 2).

Unit 3: Elaboration in the form of warning against potential consequences (sentence 3).

Unit 4: Conclusion and rebuke for passive stance (sentence 4).

Unit 5: Justifying warning and rebuke (sentence 5).

Unit 6: Conclusion posed in the form of reiterated warning (sentence 6).

Figure 1:

A semantic display of the discoursal units comprising the text 
The SL conjunctives to be discussed in the analysis are the following: (see Appendices)

1. 'ið 'anna (as)

2. bal (moreover)

3. wa (so)

4. 'ayyan kāna (no matter what)

5. mimmā (thus)

A look at the translations provided of the above conjunctives reveals that they were inappropriately rendered by most of the subjects. The notion of appropriateness here refers to whether the received translation indexes the relationship underlying the discoursal units preceding and following the conjunctive in question.

\section{1.a. 'ið'anna (as)}

As shown in Figure 1 above, this conjunctive performs a double function: retrospective and prospective. It is retrospective in the sense that it derives its function from the argument in Unit 1 which sets forth a course of action that should be taken: "min wäjib ilcarab...' (Arabs should/are called upon (to)...). It is prospective in the sense that it arouses anticipations of fulfillment of an unsaid question: why? It, thus, comes as a signal that introduces an explanatory discoursal unit. Half the subjects rendered it as an additive (AND) conjunctive, thus failing to perceive the explanatory role (AS or FOR) it undertakes. Twenty per cent of the renderings came in the form of zero conjunctive, which is quite acceptable in English and tends to favor implicitness of underlying relationships between/among discoursal units (Koch 1982). Another $20 \%$ of the renderings displayed a causal relationship signalled by because. Though, on the face of it, a causal relationship might seem acceptable, it, in fact, fails to convey the explicative relationship intended to hold between units $1 \& 2-$ a relationship which cannot be deciphered via the cause-effect conjunctive because. However, the fine distinction between explicative and causal relationships is expected to be a delicate matter in the interpretation process, taking into account time pressure and the interpreters' immature experience in interpreting.

\section{1.b. bal (moreover)}

The majority of subjects (70\%) rendered bal as an adversative/contrastive conjunctive: yet, but, nevertheless, and rather. Two students (20\%) retained it as additive-elaborative conjunctive moreover and even, while the rest $(10 \%)$ retained it as a causal conjunctive.

A look at the text reveals that there is nothing adversative in the relationship between units 2 \& 3. Unit 3 comes as an elaborative additive discoursal unit intended to amplify the tone of warning and rebuke, rather than contrasting the facts in units $2 \& 3$. An adversative conjunctive, thus, twists the flow of the argument and defeats the purposes of the speaker/writer.

\section{1.c. $w a$ (so)}

$W a$ assumes a number of semantic roles in Arabic. In addition, it tends to occur at the beginning of most sentences in Arabic prose as a stylistic nonfunctional device. The $w a$, like and in child language and unplanned spoken discourse (Perera 1984; de Beaugrande 1983; Shakir 1991; Harris and Wilkinson 1985; Schiffrin 1987) is a multi-purpose conjunctive. Hence, it is no surprise that $40 \%$ of the student interpreters rendered it as and; whereas $60 \%$ considered it a stylistic device performing no semantic role, thus rendering it as a zero conjunctive. The student interpreters seem to have failed to perceive the discoursal slot the wa occupies. A closer look at the semantic display in Figure 1 uncovers a pattern of logical presentation of content: a call for action to be taken; justification of the 
call; warning against potential consequences; conclusion of argument which resonates rebuke and criticism. Hence, so will do a better job than and, as the relationship between unit 4 and the preceding units cannot be additive. The semantic display of the text shows that this is a hierarchically-structured discourse wherein macro-structures cannot be arrayed sequentially. In other words, the component macro-structures (the six units in our text) lend themselves to logical organization in which the discursive function of each can be either superordinate or subordinate to the preceding or following one, but not equatable with it by an additive relationship.

\section{1.d. 'ayyan kāna (no matter what...)}

This is an adversative conjunctive in Arabic. It is used in the text to dismiss any chance of alternative action other than the one the speaker/writer sets forth. It subordinates the significance of whatever action or stance is mentioned in the sentence/clause it initiates, and it highlights the content of the one which follows.

Sixty percent of the student interpreters were aware of its function and therefore rendered it appropriately in English; whereas $40 \%$ rendered it as whether, thus assigning it the role of a marker of alternative action. By so doing, the student interpreters who opted for this interpretation missed the pragmatic function the conjunctive undertakes in dismissing whatever alternative actions or excuses Arab states might use to justify their passive stance toward the aggravating situation of the Moslems of Bosnia and Herzegovina.

\section{1.e. $\operatorname{mimm} \bar{a}$ (thus)}

This conjunctive represents a point in the discourse at which the argument peaks. Reviewing the progression of the argument in the text prior to mimma $\bar{a}$, the recipient anticipates a concluding discoursal unit which unfolds crystal-clear a warning commensurate with the nature and progression of the preceding content. This role, however, was missed by most of the student interpreters. Forty percent of them rendered it as that or which, thus assigning it an anaphoric function rather than causal-concluding one. Semantically and pragmatically, anaphoric elements are employed for purposes of cohesive linking between textual elements, viz., substitution. Causal-concluding conjunctives, on the other hand, are not employed to substitute elements in previous discoursal units, but to interlock one unit with another on basis of the argument in both. Thirty percent of the students rendered it as and while twenty percent as nevertheless, and the rest as zero conjunctive.

\section{Concluding Remarks to Section 3.1.}

The analysis in section 3.1. has shown that the SL conjunctives have been handled in ways which distorted the source text in two of its characteristic features, viz., pragmatic orientation and formality of mode of presentation.

\section{a. Pragmatic orientation}

As shown above, the text is intended to do something with the intended audience: to bring to the fore a problem, to rebuke and blame for indifferent response, to warn against the consequences of such a stance, and finally to conclude the argument with a warning against potential unhappy consequences. This being so, the discoursal joints in this text are highly sensitive to distortion. The joints here are the conjunctives which represent the thresholds in the discourse structure, and which play a double function: leading into and out of discoursal units.

Results have shown that the student interpreters were not always aware of the significant role the SL conjunctives play in structuring the argument, and therefore their interpretation destroyed the pattern of logic the argument is intended to display to the audience. Conjunctives marking additive relationships proved to be relatively dominant in 
the student interpreters' renderings, and other conjunctives of different functions also showed failure to perceive the underlying relationships among the different discoursal units. Research in the cognitive side of discourse (e.g. Reed et al. 1985; Moffett 1968; Kinneavy 1980; Britton et al. 1975; Perera 1984) has shown that temporal and additive relationships have proved to be the easiest to handle in immature verbal expression (Odell 1983) characterized by simplistic style. Research in this area attributes such a discursive phenomenon to developing proficiency in the language. One can argue here that most of the student interpreters in this study still need to improve their proficiency in both Arabic and English. Particularly, they need intensive practice in discourse analysis and disjointing texts into their component macro-elements with a view to identifying how such elements are knitted into the whole structure.

\section{$b$. Formality of mode of presentation}

Hortative texts, whether delivered in mosques, churches, or through different types of mass media, tend to have an air of formal style and serious address. The text in hand falls into this category of discursive styles. However, a look at the interpretations rendered of this text reveals that its formal registral features have been adversely affected. The overuse of and as an equivalent to the multi-purpose Arabic wa has reduced the argument to a simplistic pattern of presentation. A quick survey of the ten versions rendered shows that different types of conjunctives recurred sixty-two times, of which twenty six were the and conjunctive, equal to $67.5 \%$ of the total number.

Relative dominance of additive conjunctives is more acceptable in aural, impromptu discourse, and in informal face-to-face communication, particularly narrative text type. (For a fuller discussion of the role of additive conjunctives, see Halliday and Hasan 1976; Schiffrin 1987; de Beaugrande 1983; Labov 1972; Labov and Waletsky 1967.)

Generic and loose paraphrases frequently encountered in the student interpreters' renderings of the text also contribute to bleaching out its characteristic features. Observe, for instance, the following expressions taken from the student' versions:
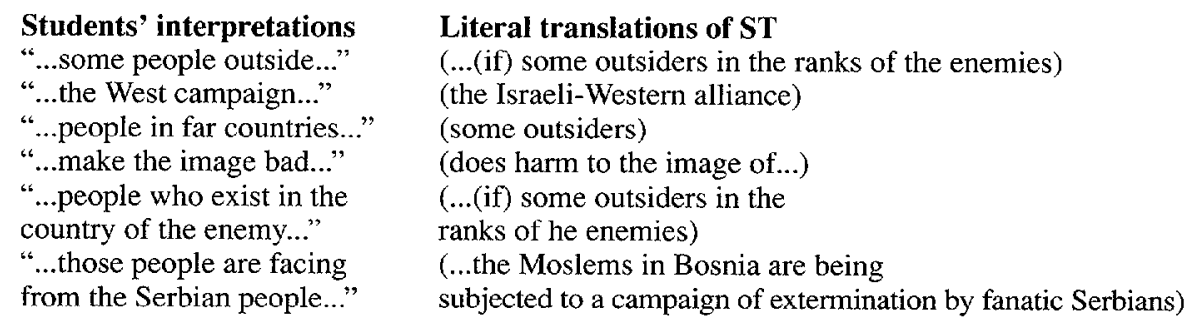

Such expressions fall short of conveying the intended message because, where they should be indicators of certain discoursal stategies, they tend to drift from the specific to the generic - a strategy which characterizes impromptu aural communication. Such general expressions figure in the generation of communication where the inexperienced interpreter tends to use them as substitutes for the target equivalents. They encourage the flow of words without engaging the interpreter in the real struggle of articulating the appropriate target expressions. However, we should admit that the student interpreters did not freely choose this style for their target expressions. Rather, they were confined to it by a number of factors, such as their limited experience in interpreting and, clearly, their unawareness of the pragmatics of conjunctive deployment at discourse unit boundaries.

\subsection{Text-Type and the Impact of Emotive Key Lexical Items}

For speakers / writers of hortative discourse, emotive lexical items play a crucial role in stimulating the listener/reader to identify with the speaker/writer with regard to the 
stances, beliefs, attitudes highlighted in the discourse. This reciprocity, as an end target for the speaker/writer, is promotable via intentional reference to shared values, beliefs, and experiences (Teeffelen 1991). In this context, lexical items function as steering devices that seek to involve the recipient in the social event, together with the ensuing reactions and emotions (Tannen 1989; Gumperz 1982), for the purposes of creating a community of rapport.

Hortative discourse, by its very nature, tends to be an intra-group address; it therefore reflects the group's values and beliefs by addressing topics shared by the members of the group. It derives its power by invoking experiences stored in the social memory of the audience. Hence, it aims at maximizing the audience's responsive attitude, solidarity, and empathy. So it is no wonder we find that such discourse unfolds prototypically in its structure, content, and emotive orientation. Prototypical discourse is identifiable by a constellation of features, among which are lexical items loaded with emotive elements deriving from a culture-specific memory repertoire (Cooper 1984; Virtanen 1992). Such emotively-loaded elements tend to key the subsequent feelings, stances and attitudes of the addressees (the in-group members). They, thus, operate as a set of signs crucial to the process of social referencing in which emotive elements help the recipient to assess how the upcoming discoursal information may unfold. Emotively-charged items are not deployed in the text to connect discoursal units, but to establish participant coordination by evoking historical, social, and emotional feelings associated with subjects, people, or concepts.

In this section, renderings of four emotive lexical items will be analyzed. These items are:

$\begin{array}{ll}\text { mihnah } & \text { (affliction/plight) } \\ \text { 'ibādah } & \text { (extermination) } \\ \text { hamajiyyah } & \text { (barbaric/savage) } \\ \text { yulăh } & \text { (fanatics) }\end{array}$

A careful study of the text reveals that these lexical items operate at both the textual and contextual dimensions. At the textual level, the items assume significance in the fact that they establish texture. Mihnah (affliction/plight), for example, collocates with other key expressions in the text, viz. tadämun (solidarity), tacătuf (sympathizing); and madàlim tärīxiyyah (historical injustices) collocates with hamlat-il-'ibāda-l-hamajiyya (the barbaric extermination compaign); while yulāh collocates with małălim and $\breve{s} a^{c} b$-il-bōsna wa-lhirsik (people of Bosnia and Herzegovina).

At the extra-textual level, the five items play a crucial cognitive role, as they draw upon the historical cognitive memory of the in-group member, addressess - a discoursal phenomenon long established in this type of text. The influence of the five items thus transcends the textual boundaries to reach out to the historical memory, as we see, for instance, in hamlat-il-'ibäda-l-hamajiyya. Such an expression calls into active memory what happened to the Moslems in the Abbasid Bagdad when the Moguls stormed the city, killing thousands of its inhabitants and destroying the city's cultural achievements. It also calls into active memory the massacre of Moslems in Moslem Andalusia, and the massacre of Palestinians in the Sabra and Shateela camps in Lebanon in 1982.

The students' renderings of the four lexical items will be discussed under four headings:

a. Missing (no equivalent provided).

b. Generalized (the equivalent generated is too general to retain the target meaning).

c. Misinterpreted (when the equivalent generated is erroneous).

d. Appropriately interpreted (when the target equivalent generated retains the feature of the source term). 


\section{2.a. mihnah kubrā (great affliction/plight)}

Table 1 below shows that only $10 \%$ of the student interpreters grasped the emotive impact of the expression, and that the rest of them either skipped it, thus adopting an avoidance strategy, or provided a too general equivalent, thus adopting a generalizing strategy (Farghal and Shakir forthcoming; Shakir and Farghal forthcoming).

\begin{tabular}{|c|c|c|c|}
\hline Missing & Generalized & Misinterpreted & Approp. interp. \\
\hline $40 \%$ & $50 \%$ & - & $10 \%$ \\
\hline
\end{tabular}

Table 1:

The students' renderings of mihnah kubrā

The table shows that $40 \%$ skipped this key expression, thus leaving a semantic and pragmatic slot unfilled in the text. Half of the students, for want of appropriate equivalents, sought generalized equivalents in the TL. Thus, we have mihna interpreted as problem, crisis, issue. These renderings lie far from mihnah, in its semantic field. They incorporate the feeling of tension related to mihnah, but they lack other characteristic emotions blended into it, namely human suffering, and anticipated empathic response on the part of the addresses. Producing an equivalent stripped of its emotive content tends to defeat the speaker/writer's pragmatic goal, which is to emotionally involve the audience in the human suffering of the Moslems in Bosnia. The likely response of the addressees to the students' equivalents is more that of uninvolved observers distanced to a great extent from the event than that of addressees with comparable experiences still resonant in their social and historical memory.

\section{2.b. 'ibādah (extermination)}

'ibãda here co-occurs with hamlah (campaign) to trigger sad memories in the addressees related to Arabs' and Moslems' ancient and recent histories (cf. discussion in the introduction to section 3). Table 2 below shows that $50 \%$ of the students ignored this expression, leaving a crucial semantic and pragmatic slot unfilled. On the other hand, $30 \%$ provided generalized equivalents which fall short of the emotive element in 'ibädah and which do not necessarily imply massacre and bloodshed. Among the attempted TL equivalents are attacking, and killing.

\begin{tabular}{|c|c|c|c|}
\hline Missing & Generalized & Misinterpreted & Approp. interp. \\
\hline $50 \%$ & $30 \%$ & - & $20 \%$ \\
\hline
\end{tabular}

Table 2:

The students' renderings of 'ibādah

\section{2.c. hamajiyyah (barabaric/savage)}

This Arabic lexical item is fraught with emotions of anger, resentment, bitterness, and abhorrence. A TL equivalent in which the above emotions are missing will be a defective counterpart failing to retain the strong implications in hamajiyyah. 


\begin{tabular}{|c|c|c|c|}
\hline Missing & Generalized & Misinterpreted & Approp. interp. \\
\hline $20 \%$ & $10 \%$ & $50 \%$ & $20 \%$ \\
\hline
\end{tabular}

Table 3:

The students' renderings of hamajiyya

Table 3 shows that $50 \%$ of the students provided erroneous TL equivalents: strong, unsystematic, gypsy, arrogant, and aggressive. A closer look at these attempted equivalents suggests that the students, in their search for appropriate TL words, proceeded by way of some common components between hamajiyyah and those words, such as chaos in unsystematic, remoteness from civilization in gypsy, and illegitimacy and uncurbed force in aggressive.

\section{2.d. $\gamma u l \bar{a} h$ (fanatics/extremists)}

Table 4 below shows that $50 \%$ of the student interpreters provided too general and loose TL equivalents, e.g. Serbian people, who claim nationalism, Serbian nationalists, unhuman Serbians. Thirty per cent omitted the expression, while $20 \%$ rendered it appropriately.

\begin{tabular}{|c|c|c|c|}
\hline Missing & Generalized & Misinterpreted & Approp. interp. \\
\hline $30 \%$ & $50 \%$ & - & $20 \%$ \\
\hline
\end{tabular}

Table 4:

The students' renderings of $\gamma u l \bar{a} h$

Using such expressions is a great drain on the force of argument the word $y u l a \bar{h}$ infuses into the text. This code word, saturated with meanings, has been discharged of such meanings when the elements of extremism, excessive zeal, unheedful ardent religious or partisan fanatical enthusiasm have been left off and it is substituted for by flat and hazy words which fall far below the intended pitch of the argument. Nationalists, for example, is not an equivalent of $\gamma u l a \bar{h}$, as it incorporates into its semantic structure positive elements universally acceptable in nationalists defending their homeland against foreign aggression - a situation which does not apply, at least in the speaker's view, to Bosnia and Herzegovina. Nor does the Serbian people perform the job of $\gamma u l a \bar{h}$, as the former is a generalization which encompasses the engineers of the massacre, as well as those who are neutral or against what is going on in the former Yugoslav Federal Republic.

\section{Concluding Remarks to Section 3.2}

Did the student interpreters consciously choose the style and expressions they used in their interpreting of the SL text? Most probably they did not; their resources were not equal to the task of mapping this text, and as a result it becomes a scattering of impressionistic and fuzzy trails of meanings and implicatures in the TL. The students seem to have headed into terra incognita with much of their equipment missing or unsuited to the nature of the area of discourse. They discover the need of the things they do not have, and, with no time to make amends, they have to fabricate, by mother wit and whatever linguistic instruments are at hand.

The study is an attempt (and in our view should be followed by other complementary ones) to show by examples the range of problems that our student interpreters encounter 
in their training courses. Their condition prior to engaging in the interpretation process, and the conditions (i.e. the pedagogies) that co-exist with the training process, have a significant bearing on the interpretation output. Such conditions need to be reconsidered, and courses more relevant to the interpretation process should be introduced in the program. Intensive courses in discourse analysis should be introduced, where students can study and analyze different types of texts, identifying as they go the role of conjunctives and lexical items in realizing the aims of the author of the text. They should be trained in how to retain the SL message by providing equivalent items both at the micro and macrolevels. The psychology of listening and the cognitive mechanisms that promote effective listening should also be introduced into the program. The connection between verbal memory and expanding this memory should be among the aims to be sought in such a course. Students who are not yet aware of discourse strategies in the TL should be advised not to enrol in an interpretation program.

\section{REFERENCES}

BOWEN, D. and M. BOWEN (1984): Steps to Consecutive Interpretation, Pen and Booth.

BRITTON, J. et al. (1975): The Development of Writing Abilities: 11-18, London, MacMillan Education.

CATFORD, I. (1965): A Linguistic Theory of Translation, London, Oxford University Press.

COOPER, D. (1973): Philosophy and the Nature of Language, London, Longman.

DE BEAUGRANDE, R. (1983): "Linguistic and Cognitive Processes in Developmental Writing", IRAL, XXI (2), pp. 125-141.

DE WARD, J. and E. NIDA (1986): From one Language to Another: Functional Equivalence in Bible Translating, Thomas Nelson Publishers.

FARGHAL, M. (1995): "Lexical and Discoursal Problems in English-Arabic Translation", Meta, 40 (1), pp. 54-61.

FARGHAL, M. and A. SHAKIR (forthcoming): "Lexical Specificity and the Student Interpreter from Arabic into English", Multilingua.

GUMPERZ, J. (1982): Discourse Strategies, Cambridge, Cambridge University Press.

HALLIDAY, M. and R. HASAN (1976): Cohesion in English, London, Longman.

HARRIS, J. and J. WILKINSON (Eds.) (1985): Readino Children's Writing, London, Allen and Unwin.

HATIM, B. and I. MASON (1990): Discourse and the Translator, London, Longman.

JAKOBSON, R. (1959): "On Linguistic Aspects of Translation", R. Brower (Ed.), On Translation, Harvard University Press, pp. 232-239.

KINNEAVY, J. (1980): "The Relation of the Whole to the Part in Interpretation Theory and in the Composing Process", Language and Style, XIII (3), pp. 1-23.

KOCH, B. (1982): "Presentation as Proof: The Language of Arabic Rhetoric", Anthropological Linguistics, 25 (1), pp. 47-57.

LABOV, W. (1972): "The Transformation of Experience in Narrative Syntax", Language in the Inner City, pp. 354-396.

LABOV, W. and J. WALETSKY (1967): "Narrative Analysis: Oral Versions of Personal Experience", J. Helm (Ed.), Essays in the Verbal and Visual Arts, Seattle, University of Washington Press, pp. 12-44.

LONGACRE, R. and S. LEVINSOHN (1978): "Field Analysis of Discourse", Wolfgang Dressler (Ed.), Current Trends in Linguistics, New York, Walter de Gruyter, pp. 103-122.

LOTFIPOUR-SAEDI, K. (1990): "Discourse Analysis and the Problem of Translation Equivalence", Meta, 35 (2), pp. 389-397.

MOFFETT, J. (1968): Teaching the Universe of Discourse, New York, Harvard University.

NIDA, E. (1977): "The Nature of Dynamic Equivalence in Translating", Babel, XXIII, pp. 99-103.

NIDA, E. (1990): “The Role of Rhetoric in Verbal Communication", Babel, 36 (3), pp. 143-154.

ODELL, L. (1983): "Redelining Maturity in Writing", A. Freedman et al. (Eds.), Learning to Write: First Language/ Second Language, London, Longman, pp. 98-113.

OCHS, E. and B. SCHIEFFELIN (1989): "Language Has a Heart", Text, 9 (1), pp. 7-27.

PERERA, K. (1984): Children's Writing and Reading, London, Basil Blackwell.

REED, M. et al. (1985): "The Effect of Writing Ability and Mode of Discourse on Cognitive Capacity Engagement", Research in the Teaching of English, 19 (3), pp. 283-295.

SCHIFFRIN, D. (1987): Discourse Markers, Cambridge, Cambridge University Press

SHAKIR, A. and M. FARGHAL (forthcoming): "Collocations as an Index of L2 Competence in Arabic-English Simultaneous Interpreting and Translation", FIT Newsletter.

SHI-XU (1992): "Argumentation, Explanation, and Social Cognition", Text, 12 (2), pp. 263-293.

TEEFFELEN, T. (1991): "Argumentation and the Arab Voice in Western Best sellers", Text, 11 (2), pp. 241-267. 
TANNEN, D. (1989): Talking Voices: Repetition, Dialogue, and Imagery in Conversational Discourse, Cambridge, Cambridge University Press.

VIRTANEN, T. (1992): “Issues of Text Typology: Narrative - a 'Basic' Type of Text", Text, 12 (2), pp. 293-310.

\section{A.PPENDIX 1}

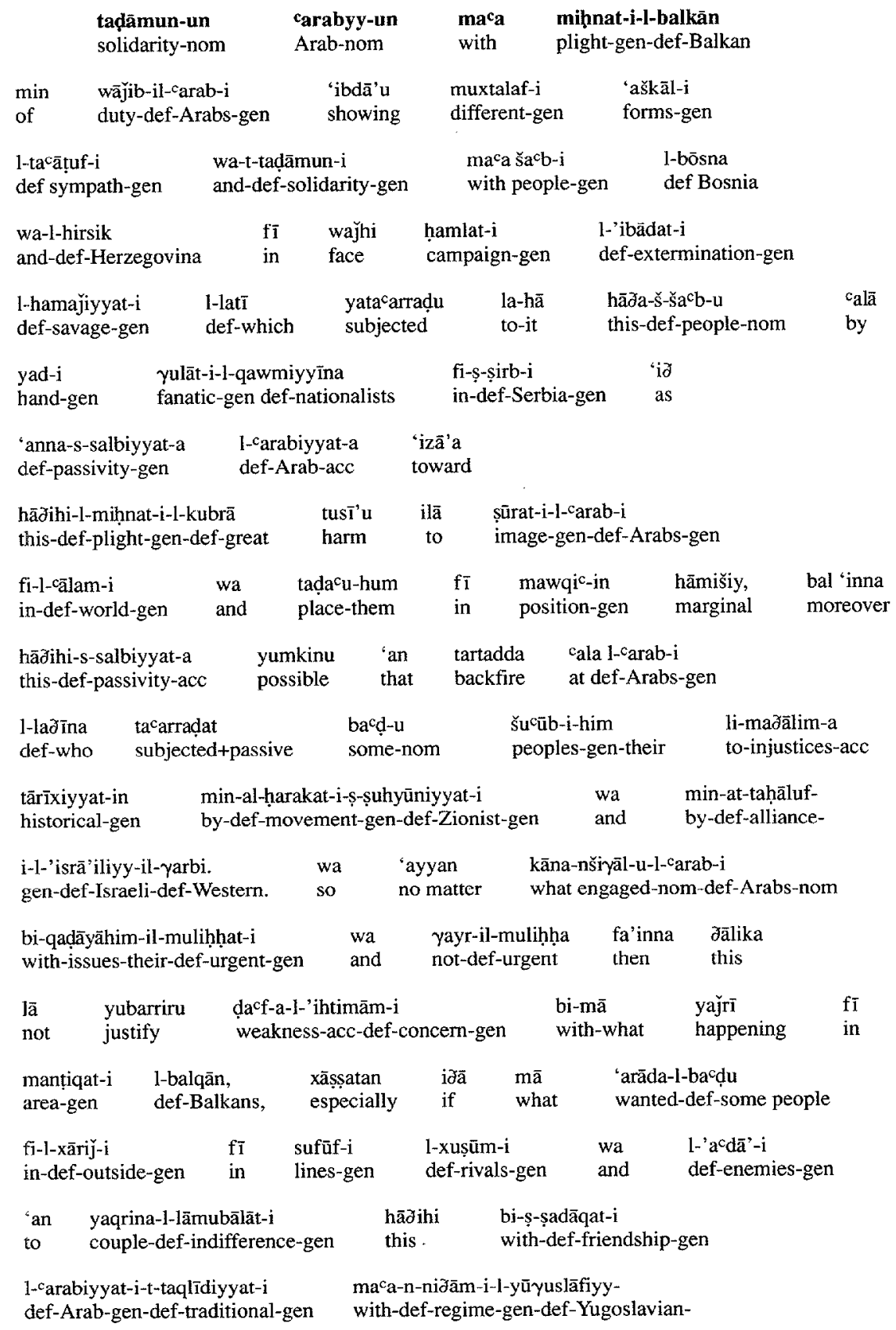




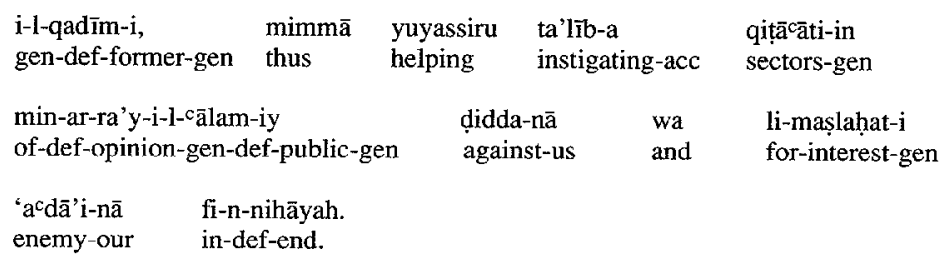

\section{APPENDIX 2}

Arab Solidarity with the Plight in the Balkans

Arabs are called upon to express different forms of sympathy and solidarity with the people of Bosnia Herzegovina against the savage campaign to which this people has been subjected by Serbian fanatics. The passive Arab stance towards this great plight does a lot of harm to the image of the Arabs in the world and places them in marginal position. Moreover, this passivity can backfire on the Arabs, some of whose people had been subjected to historical injustices by Zionism and the Israeli-Western alliance. So, no matter how the Arabs might be engaged in urgent or non-urgent issues, this may not justify their lack of interest in what is going on in the Balkans, especially if some outsiders in the ranks of enemies and rivals couple this indifference with the traditional Arab frienship with the former Yugoslavian regime, thus helping to sway some sectors of public opinion against us, and in the end, in the interest of our enemies. 